\title{
PERAN ISTRI DALAM STRATEGI ADAPTASI EKONOMI KELUARGA PASCA PROSES PENGGENANGAN WADUK JATIGEDE DI DESA TARUNAJAYA
}

\author{
Dedeh Rani Fardiawati ${ }^{1}$, Oekan S. Abdullah ${ }^{2}$, M. Fadhil Nurdin ${ }^{3}$, \\ Opan S. Suwartapradja ${ }^{4}$ \\ 1. Program Studi Pascasarja FISIP Universitas Padjadjaran \\ dfardiawati@gmail.com
}

\begin{abstract}
ABSTRAK
Penggenangan Jatigede telah mengakibatkan perubahan sosial pada masyarakat terkena dampak. Hilangnya lahan pemukiman dan lahan pertanian merubah mata pencaharian utama yang sekaligus menurunkan tingkat kesejahteraan keluarga. Upaya suami dalam mencari pekerjaan terhambat usia, kesempatan dan keahlian. Untuk mempertahankan kesejahteraan keluarga, istri turut berperan dalam melakukan strategi adaptasi sosial ekonomi dengan memanfaatkan peluang yang ada sesuai dengan keahlian, pengalaman dan modal yang mereka miliki. Strategi adaptasi sosial ekonomi yang dilakukan di sektor pertanian, peternakan dan non pertanian. Penelitian ini menggunakan metode campuran sequential explonary dimana pengumpulan data kualitatif dilakukan terlebih dahulu dan ditunjang dengan data kuantitatif. Penelitian ini menggunakan teori adaptasi dari Hardestry (1977) dengan menitik beratkan pada strategi adaptif yang dilakukan istri dalam merekonstrusi sosial ekonominya. Berdasarkan hasil penelitian, pasca penggenangan terjadi perubahan strategi istri dalam mencari nafkah, disektor pertanian i dari $28 \%$ menjadi $6 \%$, perikanan meningkat menjadi $2 \%$, non pertanian meningkat dari $32 \%$ menjadi $52 \%$, ibu rumah tangga tetap 20\%. Penentuan jumlah responden menggunakan rumus slovin dengan hasil sebanyak 80 orang. Istri terdampak memerlukan pembinaan peningkatan pengetahuan dan akses untuk mendapatkan modal dengan bunga ringan agar dapat membangun sosial ekonomi mandiri agar adaptasi sosial ekonomi yang mereka lakukan berhasil.
\end{abstract}

Kata Kunci: Peran Istri, Strategi adaptasi sosial, Ekonomi Keluarga, Penggenangan Jatigede.

\begin{abstract}
The inundation of Jatigede Dam triggered a social change to the impacted community. The loss of residential area and agricultural lands have changed the people's livelihood and slashed the family income. The husbands' efforts to find substitute jobs were hampered by age, employment opportunities, and skills. The wives play a role in maintaining family welfare to maintain family welfare by taking advantage of opportunities by their expertise, experience, and capital. Their socio-economic adaptation strategies carried out in agriculture, fishery, and non-agriculture. This research utilizes the mixing method (sequential-explanatory), the qualitative data supported by the quantitative data. Using the adaptation theory from Hardestry (1977), focusing on the adaptive strategies undertaken by the wives in their socialeconomic reconstructing, post-inundation, occurred changes the number of wives in the agricultural sector decreased from $28 \%$ to $6 \%$, fishery increase to $2 \%$, non-agriculture increased from $32 \%$ to $52 \%$ and housewives remained $20 \%$. Determination 80 people respondents number using Slovin formula. The wives need to provide guidance and easy access to low-interest funding for these wives to build their social-economic life will be successful.
\end{abstract}

Keywords: The Role of Wife, Social Adaptation Strategy, Family Economic, Inundation.

\footnotetext{
2,3,4. Program Studi Pascasarjana FISIP Universitas Padjadjaran oekan@unpad.ac.id,m.fadhil.nurdin@unpad.ac.id,opan.s.suwartapradja@unpad.ac.id
} 


\section{Peran Istri Dalam Strategi Adaptasi Eknnami Keluarga \\ Pasca Proses Penggenangan Waduk Jatigede di Desa Tarunajaya}

\section{PENDAHULUAN}

Pembangunan waduk merupakan salah satu upaya pemerintah yang ditujukan untuk meningkatkan dan memeratakan kesejahteraan rakyat. Dengan adanya pembangunan waduk, diharapkan dapat memberikan kecukupan air bagi lahan pertanian tandus di sekitarnya. Pembangunan sebuah waduk berhubungan dengan hilangnya lahan sumber mata pencaharian dan pemukiman masyarakat terdampak. Demikian halnya dengan waduk Jatigede yang telah menghilangkan lahan pertanian dan pemukiman sekitar 4.946 hektar. Permasalahan yang muncul sejak awal proses pembangunannya berkaitan dengan ganti rugi lahan, relokasi dan tinggalan budaya (Ela, 2012; Yuzar, 2015). Dengan hilangnya lahan pertanian dan pemukiman, penduduk yang terdampak mencari lahan dan pekerjaan ditempat baru. Peralihan mata pencaharian merupakan tindakan masyarakat dalam menanggulangi tekanan yang cenderung bermusim dan merupakan strategi keberlangsungan hidupnya (Ratna, 2013). Proses perpindahan dari wilayah genangan ke tempat baru, menimbulkan perubahan sosial ekonomi masyarakat terdampak menurun yang berakibat pada menurunnya kesejahteraan sosial keluarga (Winda, 2017).

Penggenangan waduk Jatigede memberikan dampak positif dengan munculnya beberapa jenis usaha baru. Petani yang kehilangan lahan, melakukan strategi adaptasi untuk mencari pendapatan dengan cara pemberdayaan ekonomi non pertanian (Harahap, 2016). Tabasum Khun menyimpulkan dalam penelitiannya bahwa pembangunan waduk-waduk raksasa membuat penduduk terdampak mengalami kemiskinan (Ruhi, 2012). Demikian halnya dengan pembangunan waduk Jatigede yang menimbulkan dampak negatif dengan munculnya masalah sanitasi dan hilangnya mata pencaharian di sektor pertanian yang menimbulkan kemiskinan. Faktor usia, kesempatan usaha dan peluang pekerjaan yang terbatas menjadi kendala kepala keluarga dalam mencari mata pencaharian pengganti (Winda, 2017: Risa, 2018). Peran anggota keluarga sangat diharapkan dalam proses penyesuaian diri dengan lingkungan agar resiko buruk dapat dihindarkan (Soekanto, 2014). Pada kondisi kepala keluarga tidak dapat memenuhi kebutuhan atau penghasilan yang tidak mencukupi, istri merupakan anggota keluarga yang dapat membantu mencari nafkah di samping mengerjakan tugas domestiknya (Rina, 2015; Asmiyati, 2016; Suparman, 2017).

Desa Tarunajaya merupakan salah satu desa yang menjadi tujuan masyarakat terdampak untuk melanjutkan hidupnya. Desa yang memiliki luas 331.245 ha ini, menampung $461 \mathrm{KK}$ dari wilayah tergenang. Masyarakat terdampak yang menetap di Desa Tarunajaya mengalami perubahan dalam mata pencaharian mereka. Sebelum penggenangan, mata pencaharian 
masyarakat terdampak lebih banyak berada di sektor pertanian. Pasca penggenangan, mereka terpaksa harus mencari pekerjaan di sektor non pertanian. Sulitnya peluang pekerjaan bagi kepala keluarga menyebabkan anggota keluarga lain ikut mencari nafkah (Azizah, 2017). Peran istri dalam strategi adaptasi ekonomi dapat dilihat dari upaya yang dilakukan dengan memanfaatkan peluang yang ada baik di sektor pertanian, peternakan dan non pertanian dengan modal dan keterampilan yang mereka miliki (Pudjiwati,1983; Kusnadi, 2000; Suharto, 2009; Abdoellah, 2017).

\section{METODE PENELITIAN}

Penelitian ini menggunakan metode campuran atau mix method sequential explanatory dimana pengumpulan data kualitatif dilakukan terlebih dahulu kemudian data kuantitatif menjadi data yang menunjang pada kualitatif (Cresswell, 2017). Metode ini penulis gunakan untuk menjawab masalah penelitian dan memberikan gambaran yang kuat mengenai sebaran pilihan strategi adaptasi sosial ekonomi keluarga yang dilakukan oleh istri terdampak pasca penggenangan. Pada penelitian ini data kualitatif diperoleh dengan cara observasi, wawancara dan kuisioner terhadap informan kunci yaitu aparat pemerintah, kepala desa dan staf Desa Tarunajaya. Sedangkan informan biasa adalah istri terdampak yang bertempat tinggal di Desa Tarunajaya. Teknik penelitian yang dilakukan dalam mengambil sampling dengan menggunakan teknik simple random sampling, dimana peneliti memberikan kesempatan yang sama kepada seluruh istri terdampak sebagai populasi. Jumlah populasi sebanyak 392 istri terdampak dengan penghitungan sampel mengacu pada teknik yang dikemukakan oleh Slovin diperoleh sampel sebanyak 80 orang istri terdampak (Sugiyono, 2011). Validasi data kualitatif dilakukan dengan metode triangulasi dan dianggap valid apabila seluruh data tidak terdapat perbedaan. Sedangkan validasi data kuantitatif dilakukan pengukuran berulang dan dianggap reliabel apabila hasil yang diperoleh sama dengan menggunakan tolok ukur yang sama.

\section{KERANGKA TEORI/KONSEP}

Hilangnya lahan pemukiman dan lahan pertanian yang disebabkan oleh penggenangan waduk Jatigede yang merubah kehidupan sosial masyarakat terutama pendapatan keluarga. Permasalahan yang muncul pasca penggenangan adalah terbatasnya peluang pekerjaan, selain itu faktor usia, keterampilan dan pendidikan sangat mempengaruhi pekerjaan yang didapatkan. Untuk mengatasi permasalahan tersebut, istri yang merupakan anggota keluarga yang memiliki hak dan kewajiban yang sama dengan suami ikut berperan dalam mempertahankan ekonomi keluarganya. Istri memanfaatkan peluang yang ada dalam melakukan strategi adaptasi sosial ekonominya. Strategi adaptasi sosial ekonomi yang dilakukan istri untuk menambah pendapatan

82 | SGSIOGLLBAL : Jurnal Pemikiran dan Penelitian Sosiologi, Vol. 4, №. 2, Juni 2020 
dengan memanfaatkan peluang yang ada di sektor pertanian, perikanan dan non pertanian dengan modal dan keterampilan yang mereka miliki. Penelitian ini menggunakan teori Hardestry (1977) dengan memusatkan perhatian pada peran istri terdampak dalam strategi adaptif untuk merekonstruksi sosial ekonomi keluarganya, dengan tujuan untuk mempertahankan kesejahteraan keluarga sebagai akibat dari menurunnya pendapatan pasca penggenangan waduk Jatigede. Peneliti melihat strategi adaptasi sosial ekonomi yang dilakukan pasca penggenangan dengan membandingkan strategi yang dilakukan sebelum penggenangan yang mencakup pelaksanaan gagasan dengan memanfaatkan peluang yang ada, sumber modal yang dipakai dan pembuatan keputusan dalam keluarga.

\section{PEMBAHASAN}

\section{Kondisi Keluarga Terdampak}

Proses penggenangan telah merubah mata pencaharian keluarga terdampak yang secara langsung merubah pendapatan mereka. Berdasarkan hasil penelitian, perubahan mata pencaharian terbanyak terjadi pada jenis pekerjaan pertanian, baik pemilik maupun buruh pertanian (Tabel 1).

Sebelum penggenangan, mata pencaharian terdampak yang bergerak di bidang pertanian sebesar 34\%. Jumlah tersebut terdiri dari $29 \%$ merupakan buruh tani dan 5\% merupakan petani sekaligus pemilik lahan. Dengan hilangnya lahan pertanian menurunkan jumlah responden yang bergerak di sektor pertanian menjadi 9\% sebagai buruh tani. Demikian halnya dengan sektor peternakan yang terhambat oleh lahan sehingga terjadi penurunan dari $9 \%$ menjadi $4 \%$ responden. Sektor non pertanian menjadi pilihan untuk mencari peluang baru, jumlah terbanyak adalah pada pekerjaan serabutan sebanyak 20\%. Selain itu, menjadi pedagang makanan merupakan pilihan yang minati oleh suami terbukti dengan meningkatnya peminat dari 3\% menjadi 8\% (Tabel 1). Mata pencaharian yang menghilang seiring penggenangan adalah perangkat desa, pemilik lahan. Sedangkan juru masak disebabkan oleh alasan kesehatan menjadi tidak bekerja. Penggenangan waduk Jatigede selain menurunkan dan menghilangkan beberapa jenis mata pencaharian, juga memberikan peluang baru seperti menjadi buruh pasar, pegawai swasta, mencari ikan dan perahu.

Berubahnya mata pencaharian sekaligus merubah pendapatan yang didapatkan oleh keluarga terdampak. Sebelum penggenangan, meskipun suami menjadi buruh tetapi setiap hari mereka mendapatkan pekerjaan. Walaupun pendapatan mereka dirasakan kurang, tetapi mereka mendapatkan upah hampir setiap harinya. Pasca penggenangan, sulitnya peluang pekerjaan dan semakin banyaknya orang yang mencari pekerjaan menyebabkan pendapatan yang mereka 
terima menjadi tidak menentu. Terkadang suami tidak mendapatkan pekerjaan selama berbulanbulan sehingga kebutuhan hidup menjadi tidak terpenuhi.

Tabel 1. Perubahan Mata Pencaharian Suami

\begin{tabular}{|c|c|}
\hline Tahap & Uraian \\
\hline Sebelum Penggenangan & $\begin{array}{l}\text { Mata pencaharian utama } 80 \text { responden (suami terdampak) } \\
\text { banyak yang bergerak di sektor pertanian } 34 \% \text { yang terdiri dari } \\
29 \% \text { sebagai buruh tani dan } 5 \% \text { pemilik lahan. Di sektor } \\
\text { peternakan } 9 \% \text { sedangkan di sektor non pertanian sebanyak } \\
37 \% \text { yang terdiri dari buruh bangunan } 12 \% \text {, serabutann } 9 \% \text {, } \\
\text { perangkat desa } 3 \% \text {, pedagang makanan } 3 \% \text {, juru masak } 1 \% \text {, } \\
\text { ojek } 2 \% \text {, kondektur } 2 \% \text {, rongsokan } 1 \% \text {, mebel } 2 \% \text {, buruh } \\
\text { pabrik } 1 \% \text { dan jasa servis elektronik } 1 \% \text {. }\end{array}$ \\
\hline Pasca Penggenangan & $\begin{array}{l}\text { Terjadi perubahan mata pencaharian seiring hilangnya lahan } \\
\text { pertanian penduduk, menyisakan } 9 \% \text { buruh tani dan } \\
\text { peternakan menjadi } 4 \% \text {. Sektor non pertanian meningkat } \\
\text { menjadi } 53 \% \text { : buruh serabutan } 20 \% \text {, pedagang makanan } 8 \% \text {, } \\
\text { mebel } 3 \% \text {, buruh pabrik } 2 \% \text {, jasa servis elektronik } 2 \% \text {. } \\
\text { Sedangkan mata pencaharian yang jumlahnya tetap yaitu ojek } \\
2 \% \text {, kondektur } 2 \% \text {. Mata pencaharian yang hilang pemilik } \\
\text { lahan, perangkat desa dan juru masak. Mata pencaharian yang } \\
\text { muncul dengan adanya penggenangan yaitu; buruh pasar } 4 \% \text {, } \\
\text { pegawai swasta } 2 \% \text {, melaut/ buruh jaring apung } 5 \% \text {, perahu } \\
1 \% \text {, tidak bekerja } 2 \% \text {. }\end{array}$ \\
\hline
\end{tabular}

Sumber: Hasil Survey, 2018

Dari 80 orang responden, 92\% mengaku bahwa suami mereka rata-rata dapat memenuhi kebutuhan hidup setengahnya saja (Tabel 2). Pendapatan menjadi tidak menentu dengan ratarata memiliki penghasilan Rp 50.000 hingga Rp 500.000 per bulannya atau Rp 10.000 hingga Rp 16.000 per harinya. Dengan biaya hidup per hari berkisar Rp 10.000- Rp 50.000 per hari. Sedangkan 8\% responden mengaku mendapatkan perbaikan hidup dengan meningkatnya pendapatan keluarga. Pekerjaan yang ditekuninya bergerak di sektor non pertanian, yaitu berjualan makanan dengan penghasilan per hari Rp 100.000 atau Rp 3.000.000 per-bulannya dengan pengeluaran berkisar Rp 35.000 hingga Rp 50.000 per harinya. Pada 92\% responden, terlihat pendapatan lebih kecil dari pengeluaran. Istri terdampak memanfaatkan peluang untuk meningkatkan pendapatan keluarga semenjak masih di wilayah genangan.

Tabel 2. Pendapatan Keluarga Terdampak

\begin{tabular}{ll}
\hline \hline Tahap & \multicolumn{1}{c}{ Uraian } \\
\hline Sebelum Penggenangan & Keluarga yang berpendapatan dibawah Rp 50.000/ hari \\
& dialami oleh buruh serabutan, buruh tani, pengumpul \\
& rongsokan dan kondektur. Pengeluaran mereka bervariasi \\
& berkisar Rp 10.000- Rp 50.000 per hari. Meskipun tidak dapat \\
& terpenuhi seluruhnya mereka mendapatkan pekerjaan setiap \\
& hari.
\end{tabular}

84 | SUSIOGLLBAL : Jurnal Pemikiran dan Penelitian Sosiologi, Vol. 4, №. 2, Juni 2020 


\begin{tabular}{cl}
\hline \hline Tahap & Uraian \\
\hline Pasca Penggenangan & Dengan terjadinya penggenangan waduk Jatigede, keluarga \\
& yang berpenghasilan dibawah Rp 50.000 yang rata-rata dialami \\
& oleh keluarga dari buruh baik serabutan, buruh tani, buruh \\
pasar, kondektur dengan jumlah pengeluaran yang sama & \\
& semasa di wilayah genangan. Permasalahan yang muncul \\
peluang kerja yang tidak setiap hari mereka dapatkan. & \\
& Sebanyak $92 \%$ responden mengaku penurunan pendapatan \\
& dan 8\% mengaku meningkat pendapatannya Rp 100.000/hari \\
(pedagang makanan).
\end{tabular}

Sumber: Hasil Survey, 2018

\section{Peran Istri dalam Strategi Adaptasi Sosial Ekonomi Keluarga}

Dengan melihat kondisi pendapatan keluarga mengalami penurunan, membuat istri terdampak berencana untuk ikut berperan dalam strategi adaptasi untuk menambah pendapatan bagi keluarga. Adaptasi merupakan suatu bentuk perilaku dalam memelihara kondisi tertentu mengatasi segala resiko pada kondisi yang baru atau sesuai keadaan (Hardestry, 1977). Demikian hal nya dengan istri terdampak di Desa Tarunajaya, sesuai dengan salah satu fungsi keluarga terutama dalam fungsi ekonomi. Istri melakukan perannya sebagai pencari nafkah pada kondisi yang diperlukan. Peran yang dilakukan istri dalam perencanaan strategi adaptasinya dengan mencari peluang yang ada pada sektor pertanian, peternakan dan non pertanian yang dilakukan diantara tugas domestiknya.

Sebelum penggenangan terjadi, para istri terdampak telah melakukan strategi pendapatan. Meskipun upaya mereka hanya diakui sebagai tambahan pendapatan suami, tetapi istri menunjukkan perannya dalam strategi adaptasi ekonomi keluarga (Pudjiwati,1983). Hal ini dapat dilihat pada Tabel 3 yaitu tabel mengenai peran istri dalam menambah pendapatan dan merupakan suatu tindakan adaptif istri dalam melakukan perencanaan dan keputusan dalam menambah pendapatan keluarga (Hardestry, 1977). Istri terdampak sebelum penggenangan memanfaatkan peluang sektor pertanian (Tabel 3) sebanyak 28\%, non pertanian $32 \%$ dan sebagai ibu rumah tangga saja (tidak bekerja) sebanyak $20 \%$.

Tabel 3. Peran Istri dalam Menambah Pendapatan

\begin{tabular}{|c|c|}
\hline Tahapan & Uraian \\
\hline Sebelum Penggenangan & $\begin{array}{l}\text { Istri ada yang telah ikut berperan dalam menambah pendapatan } \\
\text { keluarga disamping menjalankan tugas domestiknya. Dari } 80 \\
\text { responden istri yang memanfaatkan peluang di sektor pertanian } \\
\text { sebanyak } 28 \% \text {, non pertanian } 32 \% \text { dan tidak bekerja sebanyak } \\
20 \% \text {. }\end{array}$ \\
\hline Pasca Penggenangan & $\begin{array}{l}\text { Hilangnya lahan pertanian, menyebabkan istri yang } \\
\text { memanfaatkan peluang disektor tersebut berkurang menjadi } 6 \% \text {. }\end{array}$ \\
\hline
\end{tabular}




\begin{tabular}{ll}
\hline Tahapan & \multicolumn{1}{c}{ Uraian } \\
\hline $\begin{array}{l}\text { Sektor non pertanian meningkat menjadi } 52 \% \text { dan munculnya } \\
\text { peluang di sektor perikanan dimanfaatkan oleh } 2 \% \text { responden } \\
\text { istri terdampak dan tidak bekerja 20\%. }\end{array}$ \\
\hline \hline
\end{tabular}

Sumber: Hasil Survey, 2018

Pasca penggenangan, terjadi perubahan pada sektor pertanian menurun menjadi $6 \%$ seiring hilangnya lahan pertanian berubah menjadi waduk. Muncul sektor peternakan/perikanan sebanyak 2\%, non pertanian meningkat menjadi 52\% sedangkan ibu rumah tangga (tidak bekerja) tetap sebanyak $20 \%$.

Tabel 4. Pekerjaan Istri di Sektor Pertanian

\begin{tabular}{ll}
\hline \multicolumn{1}{c}{ Tahapan } & \multicolumn{1}{c}{ Uraian } \\
\hline Sebelum Penggenangan & Terdapat $28 \%$ istri yang menekuni sektor \\
& pertanian dengan upah perhari Rp 50.000 \\
\hline Pasca Penggenangan & Berkurangnya lahan pertanian $6 \%$ istri masih \\
& menekuni sektor pertanian dengan upah tetap \\
& Rp 50.000 per hari dan $22 \%$ mencari peluang \\
& di sektor non pertanian dengan pendapatan \\
& beragam mulai Rp 50.000- Rp 300.000 per hari. \\
\hline Sebelum Penggenangan & Tidak memiliki minat meskipun pada \\
& pelaksanaannya merek membantu suami dalam \\
Pasca Penggenangan & Mendapatkan pelatihan mengolah ikan air \\
& tawar dan membuat kere $(2 \%)$. \\
\hline \hline
\end{tabular}

Sumber: Hasil Survey, 2018

Peran istri di sektor pertanian tidak terlepas dari mata pencaharian utama keluarga (suami). Suami yang berprofesi sebagai petani cenderung melibatkan istri dalam sektor yang sama. Perannya dalam membantu pekerjaan suami sangat diperlukan karena dapat menekan biaya produksinya. Para istri bekerja di sektor pertanian baik sebagai buruh tani atau menggarap lahan sendiri. Tugas yang dilakukan mulai dengan menyiapkan bekal untuk suami, menebar benih hingga menyiangi rumput di ladang mereka. Tugas domestiknya selalu dilakukan sepulang dari ladang atau sawah dan biasanya mereka bekerja hingga pukul 12.00 siang. Sebelum penggenangan (Tabel. 4), istri yang berada disektor pertanian sebanyak $28 \%$ sedangkan pasca penggenangan menurun tajam menjadi 6\%. Upah yang didapatkan baik sebelum baik pasca penggenangan tidak mengalami perubahan yaitu Rp 50.000/hari. Pasca penggenangan, 22\% pindah ke sektor non pertanian dengan pendapatan Rp 50.000 hingga Rp 300.000 perhari. Istri yang masih menekuni profesi sebagai buruh tani, memanfaatkan pertanian yang berada di sekitar Tarunajaya terutama disekitar waduk Jatigede. Dengan pengetahuan yang terbatas pada sektor pertanian membuat mereka tetap bertahan hingga kini.

86 | SGSIOGLLBAL : Jurnal Pemikiran dan Penelitian Sosiologi, Vol. 4, №. 2, Juni 2020 


\section{Peran Istri Dalam Strategi Adaptasi Eknnami Keluarga \\ Pasca Proses Penggenangan Waduk Jatigede di Desa Tarunajaya}

Sebelum penggenangan, istri terdampak membantu suami dalam beternak tetapi tidak memiliki minat dan menjadikannya peluang usaha (Tabel 4.). Menurut mereka, beternak harus memiliki hobi terhadap hewan peliharaan. Selain itu, beternak tidak dapat diandalkan karena tidak setiap hari dapat mereka jual. Proses pemeliharaan yang memerlukan waktu yang lama sebelum dapat dijual.

Pada awal penggenangan, diantara istri terdampak ada yang telah mendapatkan pelatihan pengolahan ikan air tawar (Tabel 5). Sangat disayangkan, pengetahuan yang didapatkan hanya berfungsi sebagai pengetahuan saja. Sekitar $2 \%$ istri terdampak yang menjadi responden menekuni pengolahan air tawar atau membuat kere ikan. Pembuat kere ini pada mulanya bekerja di sektor pertanian dengan upah harian yang diterima sebesar Rp 50.000. Sedangkan hasil yang didapatkan dalam membuat kere ikan adalah Rp 25.000/ kg dengan pengerjaan lebih dari sehari terutama untuk proses pengeringan. Ikan yang mereka olah dibeli dengan harga Rp 15.000/kg. Para istri tidak memiliki minat dalam beternak ayam atau domba. Pekerjaan tersebut lebih banyak dilakukan oleh suami mereka karena hobi, meskipun pada pemeliharaannya istri terlibat dalam memberikan pakan ternak apabila suami berhalangan.

Semasa di wilayah genangan, $32 \%$ istri menekuni usaha disektor lain (Tabel 6). Ada istri yang bekerja sebagai buruh pabrik (2\%), berjualan makanan keliling ( $9 \%)$, berjualan pakaian $(2 \%)$, pengrajin opak (4\%), membuka warung makanan (4\%), warung kelontong (4\%) dan warung jenis sayuran $(4 \%)$.

Pasca penggenangan, pada sektor non pertanian terjadi peningkatan sebesar $20 \%$ menjadi $52 \%$ dengan jenis usaha warung makanan $18 \%$, berjualan makanan dan pakaian keliling $8 \%$, pengrajin opak 4\%, warung kelontong 7\%, warung sayuran 3\%. Pasca penggenangan terjadi penambahan jenis usaha yaitu; jasa toilet $1 \%$, buruh opak $4 \%$, bekerja di cafe $1 \%$, bekerja ditempat wisata $3 \%$, penagih hutang $1 \%$ dan Jasa cuci pakaian $1 \%$.

Sebelum pindah dari wilayah genangan, Istri yang bekerja sebagai buruh pabrik (2\%) terpaksa meninggalkan keluarga untuk mendapatkan penghasilan tambahan. Pendapatan yang diterima oleh istri buruh pabrik adalah Rp 75.000/hari atau sekitar Rp 2.250.000/bulan. Dengan pendapatan sebesar itu, digunakan untuk keperluan rumah tangga dan keperluan pribadi selama bekerja. Pengasuhan anak beralih kepada suami dan kerabat dekat yang tinggal berdekatan. Karena letak pabrik yang cukup jauh, istri pulang bertemu anak dan suami satu kali dalam sebulan. Pasca penggenangan istri yang bekerja sebagai buruh pabrik beralih menjadi ibu rumah tangga. Dengan demikian, pendapatan sebagai buruh pabrik menjadi hilang. Pertimbangan utama berhentinya adalah pengasuhan anak. Menyerahkan pengasuhan kepada orang lain selain 
suaminya tidak memungkinkan karena sanak saudara terdekat telah pindah ke lain tempat sedangkan untuk membayar pengasuh dianggap pemborosan.

Saat masih di daerah genangan, beberapa istri terdampak telah memiliki kegiatan usaha sendiri dengan membuka warung. Jenis warung yang mereka kelola adalah warung makanan (4\%), kelontong $(10 \%)$ dan sayuran $(5 \%)$. Lokasi warung yang dipilih ada yang di halaman sekolah tetapi lebih banyak dilakukan rumah mereka sendiri dengan pertimbangan mereka masih dapat mengerjakan pekerjaan rumah disela-sela berjualan. Untuk Warung makanan mereka menjual beraneka jenis makanan dan minuman jajanan anak sekolah seperti seblak, pop ice, cireng, dan cilok. Sehari penghasilan mereka setelah dikurangi modal awal berkisar Rp 100.000, penghasilan ini dapat membantu mereka untuk kebutuhan sehari-hari terutama untuk keperluan anak sekolah.

Terjadi penambahan jumlah warung yang tumbuh pasca penggenangan. Banyak istri yang tertarik dan mencoba melakukan strategi adaptasi ekonomi dengan membuka warung. Yang paling menonjol adalah untuk warung yang menjual jenis makanan dan minuman. Munculnya Waduk Jatigede yang dijadikan tempat wisata oleh para pendatang memberikan sebuah harapan bagi para istri. Mereka membuka warung bakso, warung nasi di sekitar lokasi waduk. Seorang informan, merupakan salah satu yang membuka warung makanan sejenis bakso. Saat ramai pengunjung, penghasilan yang didapatkan cukup untuk makan dan kebutuhan keluarga seperti keperluan sekolah anak-anak. Penghasilan warung saat ramai bisa mencapai Rp 150.000. Tetapi disaat sepi mereka hanya mengantongi Rp 50.000 bahkan kurang.

Selain membuka warung di sekitar tempat wisata, para istri memanfaatkan pendatang yang datang untuk memancing di areal waduk. Pada umumnya mereka menjual mie rebus, gorengan, kopi serta makanan ringan lainnya. Hasil penelitian menemukan keberadaan warung makanan ditempat pemancingan umum di area waduk.

Di Desa Tarunajaya selain terdapat warung makanan, ada pula warung kelontong, warung sayuran. Warung-warung ini lebih banyak berlokasi di sekitar rumah. Pasca penggenangan jumlah warung kelontong dan warung sayuran mengalami penurunan peminat. Warung kelontong berkurang $1 \%$ dan warung sayuran berkurang $2 \%$. Modal menjadi masalah bagi istri yang dulu membuka warung kelontong dan sayuran ini selain lokasi rumah yang tidak memungkinkan untuk membuka warung. Warung yang mereka buka tidak sebesar pada saat di wilayah genangan sehingga pendapatanpun menjadi menurun.

Pada saat masih di wilayah genangan, per hari mendapatkan keuntungan sebesar Rp 1.000.000. Tetapi saat ini, mendapatkan keuntungan Rp 100.000/ hari sudah dikatakan beruntung. 
Walaupun demikian, mereka tetap menjalankan usaha ini karena kurangnya pengalaman dan ketakutan justru kehilangan modal untuk usaha lain. Modal yang dulu mereka peroleh sebelum pindah, banyak terpakai untuk keperluan sehari-hari dan terpakai saat proses kepindahan.

Membuka warung menjadi peluang yang disukai oleh para istri terdampak, terutama bagi suaminya yang sakit dan sudah berusia lanjut. Tiga istri yang dulu berjualan makanan keliling terpaksa menghentikan jualan nya. Seorang istri membuka warung tahu di depan rumah karena suami jatuh sakit pasca penggenangan. Sedangkan dua orang istri lainnya membuka warung makanan di depan rumah walaupun di sekelilingnya telah banyak warung makanan yang sama jenisnya. Pada musim kemarau 2018 kondisi mulai berubah, Waduk Jatigede kehilangan debit airnya. Jumlah pengunjung berkurang bahkan tidak ada pengunjung yang datang sama sekali. Penjualan Pun mengalami penurunan sehingga banyak warung yang tutup.

Berdasarkan hasil penelitian, Beberapa istri semasa di wilayah genangan ada yang melakukan strategi adaptasi ekonomi dengan menjual makanan (12\%) dan pakaian keliling (2\%). Mereka memilih usaha ini karena tidak memerlukan modal, cukup tenaga saja. Pendapatan yang mereka peroleh sekitar Rp 50.000/ hari atau sebesar Rp 1.500.000/bulan. Penghasilan tersebut cukup membantu keperluan rumah tangga dan anak sekolah. Pasca penggenangan penjual makanan keliling menjadi berkurang hanya $8 \%$, sedangkan penjual pakaian menambah jenis penjualan dengan menjual makanan. Pendapatan mereka berkurang sekitar Rp 40.000/hari atau Rp 1.200.000/ bulan. Perubahan yang terjadi pada area mereka berjualan, semula mereka cukup berkeliling di sekitar tempat tinggalnya. Daya beli yang menurun menjadi kendala utama pasca penggenangan, sehingga mereka terkadang harus masuk keluar kampung yang cukup jauh. Para penjual makanan keliling ini, terkadang menjajakan makanan sampai ke wilayah lain yang agak jauh dari tempat tinggal mereka. Seperti yang dilakukan seorang Istri yang berjualan ke luar wilayah Darmaraja, yang harus menggunakan angkutan umum untuk pergi dan pulangnya. Ibu ini tidak membuat sendiri makanan yang dijualnya, dia hanya sekedar menjajakan milik orang lain. Apabila jualannya tidak habis terjual, Ibu ini tidak mengalami rugi dalam hal modal. Terkadang sambil menjual makanan, membawa beberapa pakaian titipan untuk dijual. Dari satu pakaian yang terjual mendapatkan untung sebesar Rp 10.000 .

Sebelum terjadi genangan, istri yang melakukan adaptasi dengan membuat makanan untuk dijajakan oleh penjual makanan keliling (3\%) dengan penghasilan sebesar Rp 150.000. Tetapi pasca penggenangan mereka menjual sendiri kuenya dengan alasan untuk mendapatkan keuntungan lebih yang biasanya diberikan untuk keuntungan pedagang keliling. Walaupun dijual 
langsung tanpa perantara, pendapatan per harinya mengalami penurunan menjadi Rp 40.000/ hari.

Sebelum penggenangan, terdapat istri terdampak yang menjadi pengrajin opak pada saat sebelum pindah (4\%). Mereka sudah menggeluti pembuatan opak walaupun pemasaran mereka masih belum melebihi wilayah lain selain Darmaraja. Pembuatan opak ini berdasarkan pesanan. Dulu harga opak ini perkantong adalah Rp 3.000. Rata-rata pesanan minimal 100 kantong, modal yang mereka perlukan kisaran 100.000 jika dikerjakan sendiri. Para istri pengusaha opak ini terkadang melibatkan para istri tetangganya, apabila sedang dibanjiri pesanan. Upah para istri membuat opak ini antara Rp 15.000 - Rp 20.000/ hari. Pendapatan bersih dari membuat opak adalah Rp 100.000/pesanan. Dalam seminggu paling banyak mendapatkan 3-4 pesanan.

Pengrajin opak ini termasuk yang konsisten terhadap usahanya, pasca penggenangan mereka konsisten dengan pilihan peluang strategi adaptasi sosial ekonomi mereka. Meskipun diantara pengrajin opak ini ada yang pernah mencoba peluang membuka warung di depan rumah, mereka kembali menekuni bidang kreasi usaha opak. Pada saat mencoba peluang lain, mereka hanya menghabiskan modal yang ada yang rata-rata mereka peroleh dari pinjaman pihak ketiga. Dalam menjalankan usaha ini, pengrajin opak dibantu oleh para istri di sekitar tempat tinggalnya untuk menjadi buruh opak (4\%) dengan upah hanya diberikan makan siang.

Dari hasil penelitian (Tabel 6), selain menjalankan strategi adaptasi yang pernah mereka lakukan saat di tempat genangan mereka mencoba strategi baru seperti jasa toilet (1\%), buruh opak (4\%), menjadi pegawai tempat wisata, di kafe remang-remang (1\%) dan sebagai penagih hutang/debt collector $(1 \%)$.

Seorang Ibu yang sebelumnya seorang ibu rumah tangga, pasca penggenangan mencoba melakukan strategi adaptasi dengan membuka jasa toilet (1\%) ditempat wisata sekitar waduk. Letak toilet yang dibangun di tempat milik pemerintah ini, berdekatan dengan warung makanan anak perempuannya. Tarif yang dikenakan pada pengguna toilet sebesar Rp 2.000. Penghasilan yang pernah diterimanya sebesar Rp 30.000/hari yang didapatkan pada awal Penggenangan waduk. Pada masa itu, banyak pengunjung yang datang dan memanfaatkan jasa toilet ini terlebih disaat liburan dan akhir pekan. Akan tetapi pada musim kemarau 2018, jumlah pengunjung sudah menurun bahkan hampir tidak ada.

Berdasarkan hasil penelitian (Tabel 6) terdapat istri terdampak yang bekerja pada sebuah tempat wisata yang dikelola oleh seorang pengusaha. Mereka menerima upah sebesar Rp 600.000 per bulan atau Rp 20.000/hari dengan jam kerja 8 jam perhari. Mereka mendapatkan kesempatan libur selama satu hari dalam seminggu secara bergiliran. Pekerjaan sebagai pramusaji di warung 


\section{Peran Istri Dalam Strategi Adaptasi Eknnami Keluarga \\ Pasca Proses Penggenangan Waduk Jatigede di Desa Tarunajaya}

lesehan di tempat wisata, memaksa istri meninggalkan kewajibannya sebagai ibu. Karena penghasilan suami yang menjadi tidak menentu dan kebutuhan untuk sekolah anak-anaknya menjadi prioritas utama, mereka rela melepaskan pengasuhan anak bergantian dengan suami bahkan melibatkan orang tua mereka.

Sekitar $2 \%$ istri responden sebelum penggenangan, mencoba peruntungan dengan bekerja di luar wilayah tempat tinggal mereka. Istri yang pergi ke kota besar, bekerja sebagai buruh di pabrik-pabrik. tetapi tidak berlangsung lama, karena jarak yang cukup jauh dengan keluarga. Pasca penggenangan mereka memilih menjadi ibu rumah tangga untuk mengasuh anak-anaknya dan menyerahkan tanggung jawab untuk mencari nafkah kepada suaminya yang bekerja serabutan.

Seorang istri dari pemulung barang rongsokan dari waduk, melakukan kegiatan memberikan jasa buruh cuci pakaian yang mendapat upah sebesar Rp 30.000/ permintaan. Dalam seminggu sang istri dapat melakukan jasa cuci ini sebanyak empat hari seminggu jadi mendapatkan Rp 120.000/ minggu. Modal yang diperlukan adalah tenaga yang cukup dan kondisi yang kuat. Dengan menjadi buruh cuci, istri dapat membantu suaminya untuk kebutuhan sehari-hari keluarga. Karena faktor usia, maka istri ini membatasi hanya 4 hari dalam seminggu yang dipakai untuk bekerja. Untuk mendapatkan pekerjaan ini, istri harus keluar dari tempat tinggalnya untuk mendapatkan permintaan mencuci pakaian dan biasanya dilakukan ditempat pemilik pakaiannya. Karena kondisi lingkungan tempatnya tinggal memiliki kesamaan yaitu kesulitan ekonomi sehingga sulit untuk mendapatkan pelanggan. Para tetangga yang merupakan keluarga terdampak, lebih memilih untuk melakukannya sendiri dibanding menggunakan jasa tukang cuci. Dengan jumlah uang sebesar itu dapat mereka gunakan untuk kepentingan lain.

Ada pula istri terdampak yang bekerja di tempat hiburan seperti di kafe remang- remang yang terdapat di dusun sekitar Waduk Jatigede diluar Desa Tarunajaya (Tabel 6). Walaupun secara tertutup tetapi istri mengakui sudah mendapatkan izin dari suami. Mereka sudah tidak tahu dengan cara apa untuk pemenuhan ekonomi keluarga. Suami dan istri ini tidak memiliki keahlian apapun sehingga untuk menutupi kebutuhan keluarga, terpaksa istri bekerja di kafe tersebut. Dengan terjunnya istri di jenis usaha ini menjadikan suami malah menjadi tidak melakukan kegiatan apapun. Karena kegiatan istrinya lebih menjanjikan, walaupun mereka sadari hal tersebut merupakan jalan yang kurang tepat apabila dilihat dari sisi keagamaan dan kesusilaan. Sang istri merasa ikhlas menjalani profesi yang agak beresiko ini, yang pasti anak dapat sekolah dan kebutuhan rumah dan keinginan pribadi dapat terpenuhi. Tidak didapatkan secara jelas pendapatan istri dari bekerja di kafe tersebut, tetapi menurutnya cukup untuk memenuhi 
kebutuhan rumah tangga dan membeli perlengkapan elektronik seperti TV, lemari es dan telepon genggam.

Seorang istri yang tidak dapat tinggal diam melihat pendapatan suami menjadi menurun, setelah mencoba membuka warung gagal karena faktor modal dan saingan usaha yang cukup banyak. Akhirnya menjadi kaki tangan rentenir untuk memberikan pinjaman dan bertugas sebagai juru tagih (Tabel 6). Para rentenir ini dulu di awal kepindahan dari wilayah genangan bebas berkeliaran, tetapi saat ini ada sedikit hambatan terutama dari para suami yang sering menghadang aktivitas mereka. Rentenir memilih salah satu dari para istri terdampak yang dianggap sanggup mengemban tugas sebagai juru tagih dan menjadi perantara memberikan penawaran pinjaman kepada para istri. Pekerjaan ini dirasakan cukup berat saat dilakukan, setiap hari tugasnya berkeliling menawarkan dan mengumpulkan dana milik rentenir. Dalam keadaan terpaksa terkadang harus bersikap tegas terhadap para istri yang telat membayar kewajiban mereka, sehingga memberikan beban moril yang cukup berat. Suami tidak merestui pekerjaan istrinya akan tetapi tidak dapat menghentikan kegiatan istrinya, karena kebutuhan rumah tangga terutama kebutuhan anak untuk sekolah. Ibu ini mendapatkan upah secara bulanan sebesar Rp 300.000 atau Rp 10.000/hari.

Tabel 6. Pekerjaan Istri Di Sektor Non Pertanian

\begin{tabular}{|c|c|}
\hline Tahapan & Uraian \\
\hline Sebelum Penggenangan & $\begin{array}{l}\text { Pada sektor non pertanian } 2 \% \text { menjadi buruh } \\
\text { pabrik dengan pendapatan Rp } 75.000 / \text { hari, } 9 \% \\
\text { menjual makanan keliling dengan pendapatan } \\
\text { Rp } 50.000 / \text { hari, } 2 \% \text { menjual pakaian dengan } \\
\text { pendapatan Rp } 50.000 / \text { hari, } 3 \% \text { membuat } \\
\text { makanan dengan pendapatan Rp } 150.000 / \text { hari, } \\
4 \% \text { pengrajin opak dengan pendapatan Rp } \\
100.000 / \text { hari, warung kelontong } 4 \% \text { dengan } \\
\text { pendapatan Rp } 1000.000 / \text { hari, warung } \\
\text { makanan } 4 \% \text { dengan pendapatan Rp } 100.000 \\
\text { dan warung sayuran } 4 \% \text { dengan pendapatan Rp } \\
150.000\end{array}$ \\
\hline Pasca Penggenangan & $\begin{array}{l}\text { Terjadi perubahan jumlah istri yang bergerak di } \\
\text { sektor non pertanian selain menekuni jenis } \\
\text { pekerjaan yang lama seperti pembuat opak } 4 \% \\
\text { pendapatan Rp } 100.000 \text { per pesanan, warung } \\
\text { kelontong } 7 \% \text { pendapatan } \mathrm{Rp} 100.000 / \text { hari, } \\
\text { sayuran } 3 \% \text { pendapatan Rp } 75.000 / \text { hari, } \\
\text { makanan } 18 \% \text { pendapatan Rp } 50.000-\mathrm{Rp} \\
150.000 \text {, jual makanan dan pakaian keliling } 8 \% \\
\text { dengan pendapatan Rp } 40.000 / \text { hari. Beberapa } \\
\text { istri menekuni pekerjaan baru seperti jasa toilet } \\
1 \% \text { dengan pendapatan Rp } 35.000 / \text { hari, } \\
\text { pegawai tempat wisata } 3 \% \text { dengan upah Rp }\end{array}$ \\
\hline
\end{tabular}

92 | SOSIOGLLBAL : Jurnal Pemikiran dan Penelitian Sosiologi, Vol. 4, №. Z, Juni 2020 
Sumber: Hasil Survey, 2018

Selain yang disebutkan diatas, ada kaum istri yang tidak bekerja dan hanya mengandalkan pendapatan suami sebanyak 40\% (Tabel 4). Sesulit apapun suami mereka mencari penghasilan untuk rumah tangga, mereka tetap tidak melakukan kegiatan untuk menambah pendapatan. Alasan yang paling banyak adalah mereka terhambat oleh pengetahuan dan modal dan pengasuhan anak. Mereka tidak tahu harus melakukan apa karena menurut mereka yang jualan sudah banyak sedangkan untuk bertani tidak memiliki lahan. Ada yang pernah mencoba peruntungan sebagai pembantu di kota besar, tetapi tidak lama mereka kembali. Alasan terbanyak para istri tetap menjalani sebagai ibu rumah tangga adalah mengenai pengasuhan anak. Suami mereka rata-rata mencari ikan di laut dan menjadi buruh serabutan. Mereka memilih mengurus anak dengan kondisi ekonomi seadanya. Bahkan seorang ibu yang tidak memiliki suami dan tidak melakukan apa-apa hanya mengandalkan pemberian dari sanak keluarga dan pinjaman dari pihak ke tiga untuk kebutuhannya sehari-hari.

\section{Sumber Modal Istri Terdampak}

Modal merupakan sejumlah dana yang diperlukan dalam menjalankan suatu kegiatan usaha dan dianggap sebagai salah satu penunjang keberhasilan. Tanpa modal sebuah rencana usaha tidak dapat terwujud (Amirullah, 2015). Modal dapat dipenuhi oleh kekayaan milik sendiri maupun berupa modal pinjaman yang diperoleh dari pihak ketiga baik perorangan yang sengaja menyediakan jasa peminjaman maupun perbankan (Mardiyatmo, 2008). Demikian halnya istri terdampak dalam menjalankan perannya sebagai pencari nafkah, terutama yang berada di sektor non pertanian.

Sebelum terjadi genangan, dalam memenuhi modal usahanya para istri terdampak memiliki alternatif meminjam kepada tetangga sekitar dan memanfaatkan Lembaga perbankan. Selain itu ada upaya mandiri masyarakat tergenang yaitu mengumpulkan beras perelek. Kegiatan perelek yang dikumpulkan setiap minggu kemudian dijual untuk dijadikan sebagai modal pinjaman masyarakat.

Pasca penggenangan, menghilangkan satu budaya saling membantu antar tetangga. Selain tempat tinggal yang letaknya terpencar, kondisi ekonomi keluarga yang rata-rata sama 
menyebabkan budaya tersebut hilang. Demikian halnya dengan budaya perelek yang hilang pasca penggenangan. Untuk memenuhi keperluan modalnya, para istri melakukan pinjaman kepada perbankan dan pihak ketiga yaitu rentenir.

Pada awal penggenangan, permasalahan modal muncul disaat mereka memulai kembali usaha. Setiap memerlukan modal mereka harus mencarinya sedangkan keuntungan sebelumnya habis untuk kebutuhan sehari-hari dan keperluan anak sekolah. Proses pinjam meminjam kepada pihak rentenir sudah bukan masalah yang harus mereka tutupi lagi di kalangan para istri terdampak. Menurut mereka meminjam kepada pihak rentenir tidak berbelit syarat nya, mereka dapat meminjam kapan saja bahkan ada yang melakukannya tanpa sepengetahuan suami. Istri terdampak menjadi sasaran bagi para rentenir yang mencari peluang di Desa Tarunajaya. Kondisi pendapatan yang menurun turut memberikan peluang bagi rentenir untuk melancarkan usahanya. Dari 80 orang responden hanya 10\% (8 istri) yang tidak memanfaatkan rentenir dan perbankan dalam pemenuhan modal dan kebutuhan keluarganya.

Pola peminjaman terhadap rentenir dilakukan dengan cara perorangan dan kelompok, sedangkan sistem pembayarannya ada yang dilakukan harian, mingguan dan bulanan. Dari data yang diperoleh, istri yang meminjam dengan pembayaran harian sebanyak $72 \%$ dari 80 orang, mingguan 54\% dan bulanan 59\%. Selain perorangan, peminjaman secara berkelompok dilakukan oleh $40 \%$ dari total 80 orang istri terdampak dengan sistem pembayaran mingguan dan 60\% melakukan dengan cara pembayaran bulanan. Dari data tersebut diketahui bahwa ada istri yang meminjam perorangan dengan pembayaran secara harian, mingguan dan bulanan dan ikut meminjam pula secara berkelompok. Kebutuhan untuk menyetor kepada rentenir dirasakan cukup membebani istri terdampak, memberikan rasa tidak nyaman karena setiap hari harus berurusan dengan penagih cicilan dan memberikan beban psikologis. Beban tersebut disebabkan banyaknya istri terdampak meminjam tanpa diketahui oleh suami mereka.

\section{Pengambilan Keputusan}

Sejak di wilayah genangan, istri terdampak memiliki wewenang untuk memutuskan dan mengatur keuangan keluarga. Setiap harinya mereka memutuskan kebutuhan keluarga dan menentukan dimana mereka membelinya. Untuk keperluan rumah tangga, istri memiliki wewenang penuh tanpa menunggu persetujuan dari pihak suami tetapi untuk keperluan lain mereka memutuskan bersama suaminya. Seperti pada saat proses kepindahan dari wilayah genangan, peran bersama suami istri terlihat dalam pengambilan sebuah keputusan untuk menentukan tempat tinggal baru.

94 | SOSIOGLLBAL : Jurnal Pemikiran dan Penelitian Sasiologi, Vol. 4, No. Z, Juni 2020 
Dalam menentukan usaha kreasi yang ditekuni saat ini, istri mengandalkan keahlian dan pengetahuannya yang didukung oleh suaminya. Dalam menentukan dan menjalankan aktifitas usahanya, istri mendapatkan saran dan bantuan dari suami bahkan keluarga. Suami dari pengrajin opak misalnya, dia mendukung istrinya membuka warung di depan rumahnya pasca penggenangan. Pada saat warung yang dikelola istrinya tidak menunjukan hasil, bahkan modal awal terpakai untuk kebutuhan sehari-hari. Suami memberikan saran untuk menekuni kegiatan lama yaitu sebagai pengrajin opak. Suami membantu istri mencari pesanan opak dan mengantarkan pesanannya. Demikian halnya istri yang membuka usaha warung baik warung makanan maupun sembako. Dengan dibantu oleh suami dan anak dalam menjalankan usahanya. Suami mengantar belanja dan membantu pekerjaan domestik pada saat istrinya menjalankan perannya mencari nafkah.

Hanya satu pengambilan keputusan yang dilakukan sepihak oleh kaum isti terdampak yaitu pada saat melakukan pinjaman pada rentenir. Dengan alasan terdesak kebutuhan mereka mengambil inisiatif memenuhi kebutuhannya dengan mengajukan pinjaman. Seperti pada umumnya, perempuan sulit untuk mengakses dunia perbankan dalam mengajukan pinjaman. Persyaratan yang harus dipenuhi dirasakan menyulitkan bagi perempuan. Salah satu syarat yang diperlukan pada saat pengajuan kredit perbankan yaitu bukti kepemilikan barang yang dapat dijadikan agunan. Sedangkan istri pada umumnya tidak menjadi pemilik dalam surat tanah atau aset berharga keluarga. Oleh karena itu, istri terdampak lebih nyaman berhubungan dengan pihak rentenir sebab tidak memerlukan persyaratan yang merepotkan. Cukup dengan identitas penduduk dana yang mereka perlukan dapat diterima pada hari yang sama. Menurut pemahaman mereka, pinjaman yang mereka ajukan kepada rentenir tidak terlalu besar dapat mereka bayar dengan cara mencicil, sehingga suami tidak perlu dilibatkan. Walaupun pada akhirnya pinjaman terhadap rentenir menjadi beban, karena banyaknya pinjaman yang mereka lakukan dan suami tetap harus ikut menanggung resiko pada saat terjadi masalah.

\section{SIMPULAN}

Peran istri dalam strategi adaptasi sosial ekonomi dapat dilihat dari cara mereka merekonstruksi merencanakan, melaksanakan gagasan dan pengambilan keputusan dalam mencari peluang untuk mendapatkan penghasilan dengan bekerja di sektor pertanian, perikanan dan non pertanian. Semenjak di wilayah genangan istri terdampak telah terbiasa dengan peran mencari nafkah tambahan bagi keluarga. Pasca penggenangan para istri terdampak lebih diperlukan perannya untuk melakukan strategi adaptasi ekonomi keluarga. Karena terbatasnya keterampilan, pengalaman dan modal, para istri lebih banyak memutuskan tetap menekuni 
kegiatan usaha yang sama semasa di wilayah genangan. Tetapi ada beberapa istri yang mencoba peruntungan lain dan tidak berhasil dan kembali ke usaha yang pernah digelutinya. Ada pula istri yang mau tidak mau harus memilih lahan usaha baru karena hilangnya kesempatan usaha lama yaitu di sektor pertanian. Para istri terdampak lebih memilih strategi adaptasi ekonominya di sektor usaha non pertanian terutama yang berhubungan dengan makanan, baik yang membuka warung makanan, sayuran dan kelontong ataupun sebagai penjual makanan keliling. Selain itu terdapat istri yang menekuni usaha sebagai pembuat dan buruh opak.

Dengan demikian dapat ditarik kesimpulan bahwa istri memiliki peranan penting dalam strategi adaptasi ekonomi keluarga pasca penggenangan waduk Jatigede, meskipun terjadi penurunan jumlah pendapatan yang diperoleh. Para istri telah melakukan strategi adaptasi ekonomi keluarganya dengan memanfaatkan peluang pada sektor yang tersedia di bidang pertanian, perikanan dan non pertanian. Bahkan beberapa istri terdampak berhasil membuka peluang usaha bagi istri lain meskipun pasca penggenangan mereka hanya dapat memberikan upah makan siang saja. Sebelum pindah, para istri terdampak mewujudkan kebutuhan permodalan dengan memanfaatkan jaringan sosial seperti meminjam kepada tetangga dan adanya kegiatan beras perelek. Pasca penggenangan keluarga terdampak memiliki pengalaman meminjam dana kepada lembaga formal seperti perbankan tetapi para istri terdampak lebih banyak memanfaatkan lembaga keuangan informal seperti rentenir.

Untuk memperkuat perannya dalam melakukan strategi adaptasi sosial ekonominya, Para istri terdampak ini memerlukan beberapa tindakan sebagai berikut: Pertama; tindakan pembinaan baik untuk usaha yang telah mereka jalankan, pemberdayaan, pemasaran maupun pelatihan peluang lain yang menggunakan sumber daya yang ada. Kurangnya pengetahuan untuk melihat peluang bisnis sehingga mereka terpaku dengan kegiatan yang sejenis cenderung meniru. Selain itu, para istri yang telah memiliki usaha lebih memilih menunggu order dan pesanan. Kurangnya pemasaran membuat usaha mereka tersendat. Perlu pembinaan dari pemerintah daerah dalam pemasaran hasil usaha mereka. Demikian pula bagi istri yang menjalankan peran tunggal, perlu adanya dorongan motivasi untuk ikut dalam strategi adaptasi ekonomi keluarganya. Dengan memperhatikan pemberdayaan istri diharapkan dapat mengurangi wajah istri yang identik dengan kemiskinan dalam keluarga. Kedua; selain itu mereka memerlukan akses untuk mendapatkan modal dengan bunga yang tidak terlalu tinggi. Pada umumnya istri memiliki kesulitan dalam mendapatkan pinjaman modal kepada pihak perbankan. Proses yang berbelit dan memakan waktu yang cukup lama, membuat para istri memilih jalan lain dalam pengadaan modal yaitu rentenir. Untuk sebuah desa dengan jumlah penduduk mencapai angka lebih dari 5 ribu jiwa sudah sepantasnya memiliki beberapa unit koperasi atau sebuah kegiatan yang dapat

马6 | SUSIOGLLBAL : Jurnal Pemikiran dan Penelitian Sosiologi, Vol. 4, №. 2, Juni 2020 
menghasilkan modal yang berasal dari mereka untuk digunakan oleh kalangan sendiri, sebagai contoh kegiatan pengumpulan beras perelek yang pernah dilakukan pada saat di wilayah genangan. Dengan adanya aktivitas mandiri, kepentingan akan modal dan kebutuhan mendesak tidak terlalu tergantung pada pinjaman dari pihak manapun. Dengan demikian strategi adaptasi sosial ekonomi yang diperankan oleh kaum istri terdampak pasca penggenangan secara bertahap menjadi lebih baik dan berhasil.

\section{DAFTAR PUSTAKA}

Abdoellah, O. S. 2017. Ekologi Manusia dan Pembangunan Berkelanjuntan. Jakarta: PT. Gramedia Pustaka Utama.

Amirullah. 2015. Pengantar Manajemen. Jakarta: PT. Mitra Wacana Media.

Annisa Nur Azizah, d. 2017. "Bentuk Strategi Adaptasi Sosial Ekonomi Masyarakat Petani Pasca Pembangun Waduk Jatigede". Sosietas, 399-406.

Anonim, PP Nomor 21.1994. Penyelenggaraan Pembangunan Keluarga Sejahtera.

Anonim, Tarunajaya. 2017. Rencana Pembangunan Jangka Menengah.

Asmiyati. 2016. "Peran Wanita dalam Menunjang Perekonomian Rumah Tangga Keluarga Petani Tradisional untuk Penanggulangan Kemiskinan di Desa Kuwil Kecamatan Kalawat". Holistik Tabun X No. 17.

Cresswell. J.W. 2017. Research Design: Pendekatan Metode Kualitatif, Kuantitatif dan Campuran(4 $4^{\text {th }}$ Ed). Yogyakarta: Pustaka Pelajar.

Ela, N. 2012. "Dampak Pembangunan Waduk Jatigede Terhadap Masyarakat Calon Genangan (Studi Sosiologi Pembangunan Desa Leuwihideung, Sumedang). UINSGD.

Harahap, D.J. 2016. "Faktor Positif dan Negatif Yang Ditimbulkan Oleh Pembangunan Waduk Jatigede". ALG, Anthropologi UNPAD.

Hardestry, D. 1977. Ecological Antropology. New York: Mc Graw-Hill.

Jurnal Tuwu, D. 2018. Peran Pekerja Perempuan dalam Memenuhi Ekonomi Keluarga dari Peran Domestik ke Peran Publik. Al-Izzah, Vol. 13 No.1.

Kajian Gender dan Anak: http:// Media.neliti.com

Kusnadi. 2000. Nelayan: Strategi Adaptasi dan Jaringan Sosial. Bandung:Humaniora Utama Press.

Mardiyatmo. 2008. Kewirausahaan. Surakarta: Yudhistira.

Martono, N. 2016. Sosiologi Perubahan Sosial, Perspektif Klasik Modern, Posmodern dan Poskolonial. Depok: PT. Rajagrafindo Persada.

Melis, M. Juni.2017. Relevansi Peran Gender dan Kontribusi Ekonomi Perempuan. Retrieved from

Pembangunan Jatigede.Umbara, Vol. 12, No. 2

Pudjiwati, S. 1983. Peranan Wanita Dalam Perkembangan Masyarakat Desa. Jakarta: Rajawali Pers.

Ratna. 2013. "Perubahan Pekerjaan Masyarakat Sebagai Akibat dari Bencana (Studi Kasus: Kawasan Wisata Volcano Tour Gunung Merapi Desa Umbulharjo, Kec. Cangkringan, Kabupaten Sleman." Perencanaan Wilayah dan Kota, Volume 24 No.1, 19-34.

Rina, S. 2015. Peran Istri dalam Perekonomian Keluarga di Desa Parit Baru Kecamatan Tambang Kabupaten Kampar. Jom FISIP Volume 2 no.1. 
Dedeh Rani Fardiawati, Dekan S. Abdullah, M. Fadhil Nurdin, Dpan S. Suwartapradja

Risa, N. 2018. "Strategi Adaptasi Masyarakat Terdampak Pembangun Waduk Jatigede di Dusun Cipondoh Desa Pawenang Kec. Jatinunggal Kab Sumedang”.Patanjala, Vol.10.

Ritzer, G. 2012. Teori Sosiologi, Dari Sosiologi Klasik Sampai Perkembangan Terakhir Postmodern. Translated by S. Pasaribu. Yogyakarta: Pustaka Pelajar.

Ruhi, T. K. 2012. Dam The Irony For Greater Common Goo A Critical Cultural Analysis of Narmada Dam Debate. International Journal of Communication 6, 194-213.

Soekanto, S. 2014. Sosiologi Suatu Pengantar. Jakarta: CV. Rajawali Press.

Sugiyono.2011. Metode Penelitian Kualitatif Kuantitatif. Bandung: Alfabeta.

Suharto, E. 2009. Membangun Masyarakat Memberdayakan Masyarakat. Bandung: Refika Aditama.

Suparman. 2017.Peran Ganda Istri Petani (Studi Kasus di Desa Perangian Kecamatan Baraka Kabupaten Enrekang. Edumaspul Volume 1No. 2, 104-114.

Wijayanto.2017. Perubahan Mata Pencaharian dan Proses Adaptasi Warga Terkena Dampak

Winda. 2017. Identifikasi Dampak Pembangunan Waduk Jatigede Terhadap Pendapatan

Masyarakat dari sektor Pertanian. Unisba.Spesia, Vol. 3, No. 1

Yuzar.P. 2015. Dampak Pembangunan Waduk Jatigede Terhadap Kehidupan Sosial Budaya Masyarakatnya.Patanjala, Vol. 7, No. 1:131-146

98 | SGSIOGLLBAL : Jurnal Pemikiran dan Penelitian Sosiologi, Vol. 4, No. 2, Juni 2020 